ELISHA P. RENNE

\title{
Mass Producing Food Traditions for West Africans Abroad
}

\begin{abstract}
In this article, I examine West African foods sold mainly in specialty grocery stores, focusing on how technologies used in food production in West Africa are referenced in the brand names and packaging of processed African foods sold in the United States. Through their association with "timeless" West African food-processing techniques, such foods evoke memories of childhood and home. Yet the transformation of West African foods through new technologies of processing, packaging, and branding reflects different time and health concerns of West African immigrants living in the United States. Through their purchase of time-saving, mass-produced, and hygienically packaged foodstuffs, which are ideologically similar to but technologically very different from the production processes and cooking in Africa, West Africans in the United States use food to maintain social relations with their particular families, hometown associations, and religious groups, while also constituting national, regional, and global connections through the reinvention of food traditions. [Keywords: food, technology, West Africa, African Diaspora, United States]
\end{abstract}

New Year meant Isara. Smoked pork, the flavour of wood smoke, red dust of the dry season, dry thatch. New Year was palm wine, ebiripo, ikokore ... a firmer, earth-aged kind of love and protection. Isara was filled with unsuspected treats, as when Father pulled down yet another ominous bundle from the rafters and it turned out to be smoked game, ageless in its preservation. ${ }^{1}$

\section{—Wole Soyinka, Aké: The Years of Childhood}

For those growing up in southwestern Nigeria in the 1940s, like the writer Wole Soyinka, places and times such as New Year celebrated in his father's home, the Ijebu Yoruba village of Isara, were often remembered in terms of food. For Nigerians who then went on to study in colleges and universities in the United States, these foods became delicacies available only on the occasional trip back to family homes in Nigeria. Thus, in Chicago in the 1970s, Nigerians, as well as other students from West Africa, had to make due with buying Betty Crocker Potato Buds ${ }^{\circledR}$ and Manischewitz ${ }^{\circledR}$ Potato Starch to make a semblance of the starchy mainstay known as fufu in Nigeria and Ghana. ${ }^{2}$ During the 1980s, however, companies in West Africa began processing and packaging local foodstuffs associated with particular West African cuisines for sale in small grocery stores in the United States, such as those located in cities and university towns where large numbers of West African immigrants resided. ${ }^{3}$ Indeed, it was the opening of these specialty grocery stores during the 1980s and early 1990s that contributed to the growth in the processed African food industry by providing marketing outlets for their products.

In this article, I focus on three aspects of West African foods sold in the United States. First, I examine the technologies used in food production in West Africa and the association of these production processes with foods sold in African grocery stores. I suggest that marketing claims that the latter are "authentically prepared" relate these food items with particular moral spaces, characterized by memories-of the affectionate intimacies "of trust, reliance, and support" (Beidelman 1985:166) as well as of deprivations-of childhood back "home" (Holtzman 2006:362). Second, I consider the transformation of West African foods through new technologies of preparation, packaging, and branding (Pavitt 2005), which mark them as modern comestibles, circumscribed by Food and Drug Administration (FDA) regulations and by different time constraints and health concerns of West Africans living in the United States. Finally, I discuss the ways that the purchase and preparation of these packaged West African dishes, which are ideologically similar to but technologically very different from the production processes associated with these West African cuisines from "home," reinforce particular social identities through various forms 
of commensal sociality and memories of cultural practices from West Africa (Lentz 1999; Osseo-Asare 2005). Through their use of time-saving, mass-produced, and hygienically packaged foodstuffs purchased at specialty West African grocery stores, West Africans in the United States both reproduce and reconstruct forms of social relations through the reinvention of food traditions from home.

\section{WEST AFRICAN GROCERY STORES AND CONSUMERS IN THE UNITED STATES}

\section{West African Food and Church Worship}

Presently, there are over 50 West African grocery stores in the United States. ${ }^{4}$ While conducting research for a project on African Diaspora connections of one Nigerian Independent Church known as the Cherubim and Seraphim (C\&S) Church (founded in Lagos, Nigeria, in 1925; see Omoyajowo 1982; Peel 1968; Renne and Agbaje-Williams 2005), I attended services in the New York (Newark 2005, Bronx 2006), Chicago (2005, 2006), and Detroit (2005) metropolitan areas. ${ }^{5}$ Food was an important element of church worship, with an assortment of Nigerian dishes served after the service. Food is also prepared for special church functions, such as Thanksgiving services, in which different branches of Nigerian Independent churches in the United States and Canada come together to celebrate church anniversaries, marked by the preparation of large quantities of food that is served to church guests. I also spoke with church members about local sources of West Africa foodstuffs and visited African grocery stores that they patronized, collecting a range of packaged African food items and locally produced newspapers oriented toward African audiences. These sources were supplemented with published materials (travel journals, novels, journal articles, and books); information from grocery store websites specializing in West African food; and the actual packaging of processed foods sold in African grocery stores. While C\&S church members represent a particular subset of West Africans living in the United States (most are Nigerian born, and many, but not all, have a Yoruba ethnic background), the practice of serving particular dishes associated with West African cuisine after church services and at other special events such as church anniversaries, marriages, and naming ceremonies is similar to that of other West African immigrants in the United States.

\section{West African Grocery Stores, Products, and Consumers}

In the Chicago area alone, such stores include the Old World Market and the African Grocery on the North Side and Chika International Market, which has two suburban locations. These stores sell both fresh produce and products associated with African cuisine-for example, plantains and large tuber yams, frozen goat meat and stockfish, processed cassava fufu flour, and canned palm kernel concentrate (Figure 1a) - and packaged snacks such as chin chin (small crunchy nuggets made from deep fried dough; see

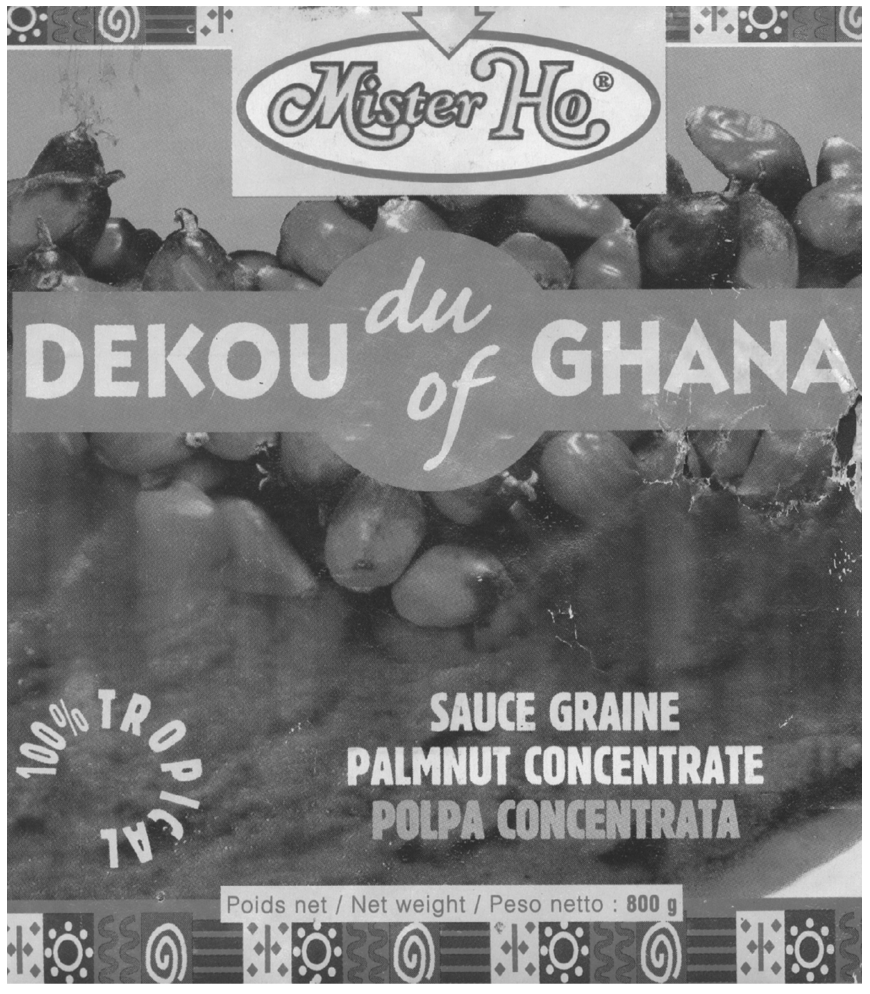

FIGURE 1a. Label from Mr. Ho ${ }^{\circledR}$ canned palm nut concentrate, "100\% Tropical," used to make palm nut soup, 2005. (Photograph by author)

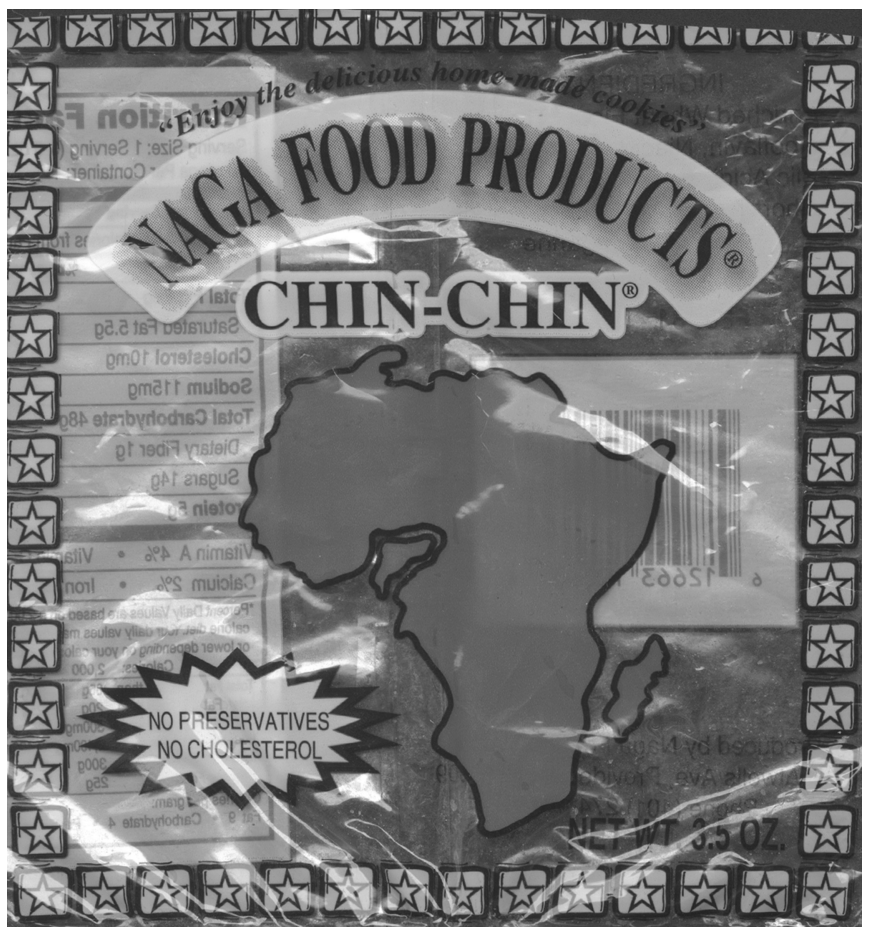

FIGURE 1b. An example of packaged snack foods: Naga Food Products ${ }^{\circledR}$ chin chin, small crunchy nuggets made from deep fried dough, 2005. (Photograph by author) 
Figure 1b). The foods sold at these stores include processed foods, either made and packaged in West Africa (such as Dandawa bouillon cubes) or processed in West Africa-in cities such as Tema, Ghana; Lagos, Nigeria; and Abidjan, Côte d'Ivoire-and then packaged and sold by distributors in the United States.

Many of these specialty West African grocery stores, known by word of mouth and through newspaper advertisements, have names that identify them to potential shoppers. These include stores with names that refer to place, such as J and B African Market, in Seattle; the African Depot, in Florissant, Missouri; the West African Grocery, in New York City; and the Sankofa International Market, in Greensboro, North Carolina. ${ }^{6}$ Other store names evoke climate, such as the African Tropical Market in Kansas City, Missouri, and Tropical Foods in Roxbury, Massachusetts. Some store names refer to particular objects associated with Africa, such as the African Hut in Laguna Beach, California; the Calabash, in Newark, New Jersey; or the Safari Food Market, in Buffalo, New York. Others refer to specific African cities, languages, or ethnicities, such as the Kumasi African, American and Spanish Grocery in Worcester, Massachusetts; the Accra Market in West Hartford, Connecticut; or the Wazobia Grocery in Brooklyn, New York. ${ }^{7}$

West African immigrants, such as C\&S Church members, are the primary consumers of the specialty foods available in these stores in the United States, purchasing them for everyday meals and festive celebrations. Foods such as palm oil are required ingredients for the preparation of particular cuisines associated with West African countries and ethnicities: for example, palm oil is essential in groundnut soup to eat with Ghanaian banku (fermented cornmeal), egusi (melon seed) soup to eat with Nigerian iyan (pounded yam), and in preparing versions of the Senegalese dish, Jollof rice (Osseo-Asare 2005). Some African grocery stores cater to particular ethnic groups or nationalities: for example, the Old World Market in Chicago carries a range of Ghanaian specialty foods and local Ghanaian newspapers. However, in these cases, specifically named Ghanaian ethnic (Ga, Asante, or LoDagaa) food cuisines (Goody 1982) associated with different geographical and climatic as well as sociocultural and political contexts may be downplayed in favor of a more general Ghanaian identity. This process is paralleled in the ways that the differences in the techniques used to prepare these foods in West Africa are homogenized through their mass production as generic instant powders and frozen entrees sold in the United States.

\section{TECHNOLOGIES OF FOOD PRODUCTION AND MEMORIES OF HOME}

But they never attempted the usual cries of "hot yams!" "sweet sauce!" ... of the girls, whose places they were attempting to fill.

\section{—T. J. Bowen, Adventures and Missionary Labours}

The particular processed forms by which West African food products are marketed in specialty grocery stores in the United States distinguish them from their counterparts sold in large markets throughout West Africa. Many of the foods sold there continue to be sold in an unprocessed bulk state through large open-air markets (Ikpe 1994), although prepared foods and snacks are often marketed by young girls and women hawkers, who carry their wares on their heads and call out their products, much as the U.S. missionary, T. J. Bowen (1968:139), observed in the town of Abeokuta in 1851, referred to in the above epigraph. Although one may buy canned tomato puree and Maggi ${ }^{\circledR}$ bouillon cubes in the market, the mainstays of many soups and sauces are onions, tomatoes, leafy vegetables, peppers, fish, and meat, all displayed in neatly piled heaps that consist of specific but unpackaged quantities. The starchy mainstays (Bascom 1951a, 1951b) of West African cuisine (such as maize, beans, and rice) are sold out of 50-pound sacks, while the main types of yam (white, yellow, water, and bitter) are sold in stacks. ${ }^{8}$ It is the association of these different foodstuffs with distinctively prepared foods that have particular sensory qualities-textures, smells, and tastes (Sutton 2001:159)—that resonate with memories of home (Holtzman 2006:367): for example, consider the association between cow-peas (Vigna unguiculata, known more commonly as black-eyed peas, which are actually a type of bean) with moin moin (steamed bean cakes) and akara (bean fritters; Ajibola and Somade 1947:18; Ekariko 2005:14). Akara is described in one of the many newspapers available in West African grocery stores as "a wholesome product made from beans ... [that] is a very popular, delicious and healthy street food delicacy from western Nigeria" (Ekariko 2005:14). Some Nigerian Americans may attempt the rigors of akara production, which takes "at least a day to prepare" because the beans must be soaked overnight and the skins entirely removed the next day. Others, however, wait until they return to Nigeria, where they can buy hot, fresh akara on the street and at motor parks.

As labor intensive and time consuming as the process of preparing akara bean fritters seems, preparations of foods such as this have their own distinctive technologies, associated with particular places, things, and people. Take, for example, the transformation of corn into the pinkish, slightly sour corn gruel known as ogi, which is a popular breakfast food, often served with akara throughout West Africa. It is made in a series of settings, connected with specific techniques and people, as described by Soyinka:

Every week, sometimes more often, Lawanle or Joseph would go off with a large basin of corn and return with it crushed, a layer of water over it. Then would begin a series of operations with calabashes, strainers, baskets and huge pots. It ended with those pots being placed in a dark corner of the kitchen, covered. As the day passed they would give off an ever ripening smell of fermentation. A week would pass and after several tests, tasting and sniffing, one pot would emerge from the darkness, and from it was scooped the smooth white paste which in turn was stirred in hot water to provide the morning ogi, a neutral mixture which everyone seemed to enjoy but I. . . Now I saw that the labour involved was even much greater than I knew, which only made matters worse for ogi, in my estimate of its pretensions. We were passing by a small shop in which 
a machine whirled, propelling a belt with enough noise to match the music of the police band. A cluster of women waited by the door with their corn-filled basins and I realized that this was where Joseph or Lawanle came on those weekly excursions. There was a basin placed under a wide funnel which opened downwards. Suddenly the whitish mixture was flushed through the basin, of the same coarse mix that Lawanle would bring home. Then they would all commence the task of refining it and leaving it for some days to settle. Mother loved the omi'kan, the sour fermented liquid which formed at the top after its period of rest. [Soyinka 1981:38-39]

Soyinka concludes his description of the extended process of ogi production with an affectionate reference to his mother's love of the sour-tasting water that collected on the top of the fermented ogi. And even while Soyinka disliked both ogi and omi'kan water, he would have been given these things to eat by his mother. This suggests that certain foods are often fed to children not only to establish taste and create memories (both positive and negative) associated with particular types of food but also to reinforce the intimate connection between mother and child, begun by breast-feeding and continued through mothers' preparation of foods for their children. ${ }^{9}$

Nonetheless, the selfless preparation and giving of food by mothers may actually be a source of unpleasant childhood memories of home for those who left areas of Africa where they experienced food scarcity and hunger (Holtzman 2006:366). Similarly, memories of a parent's lack of provision of adequate food may be seen as a sign of a failed mother-child relationship, which was expressed by a Nigerian woman who had been raised by a foster mother when young: "She used to give me very small amounts of food with only a small fish head. I used to be given the same measure of food as that of her smallest child, her last-born, but she would give her the better part of the fish" (Renne 2003:100).

These distinctive memories of food and childhood, such as the time-consuming and the labor-intensive preparation of ogi described by Soyinka, differ considerably from the preparation of "instant ogi," purchased in packages sold at West African grocery stores in U.S. cities. While advertised as having the advantage of being "microwavable," packaged ogi-made with the ingredients, corn starch, and lactic or citric acid-does not even begin to approach the taste of ogi prepared by the longer process. Not surprisingly, many African foods sold in the United States are much reduced in variety because of their standardized packaging and the confines of West African grocery stores with their limited rows of shelves and refrigerated cases. Yet despite this considerable change in the processing, packaging, and marketing of these foods, the brand names and food packaging often invoke imagery that suggest "age-old" West African production techniques-such as the fermentation of corn, the stone grinding of peppers, the hand shelling of egusi melon seeds, women painstakingly preparing meals (Curtin 1992:125) cooked over an open fire (see Figure 2), and the mortar-and-pestle pounding of grains and cooked tubers. Thus, the trademark design for Golden Tropics prod-

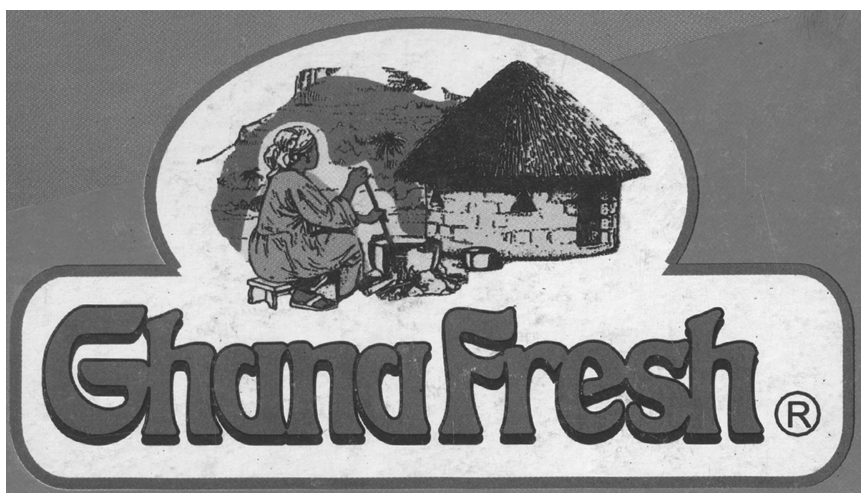

FIGURE 2. The trademark design for Ghana Fresh ${ }^{\circledR}$ products shows a seated woman, stirring a pot over a wood fire next to a grass-thatched hut, 2005. (Photograph by author)

ucts includes a map of Africa along with a woman pounding food with a mortar and pestle along side a thatched hut (see Figure 3). The raw materials used to produce the canned or packaged item may also be illustrated, as in can labels of Ruker Cream of Palm Fruits, which depict the palm nut fruits themselves (from which palm oil is made) and a large cook pot overflowing with palm nut soup. Yet despite the authenticating imagery of traditional technologies and labor-intensive production process used in the packaging of foodstuffs sold in West African grocery stores, their preparation represents new concerns about time and health.

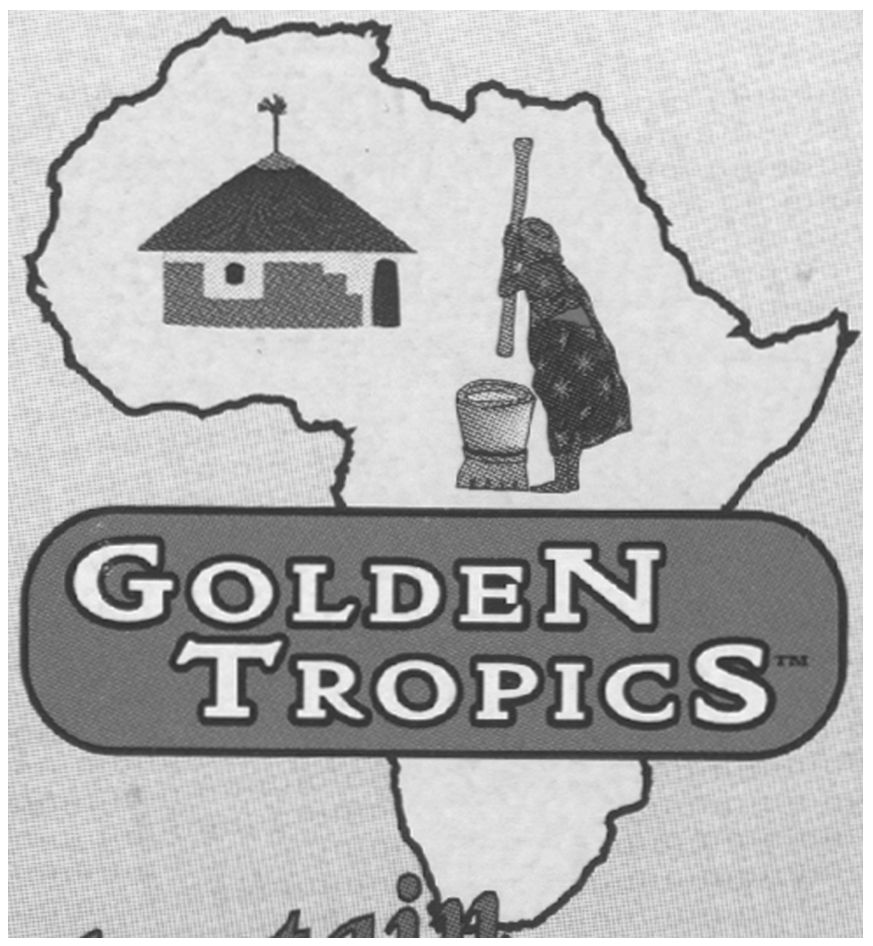

FIGURE 3. The logo for Gold Tropics ${ }^{\mathrm{TM}}$ products depicts a woman using a mortar and pestle in front of grass-thatched hut, 2005. (Photograph by author) 


\section{CHANGING TIME-HONORED TRADITIONAL WEST AFRICAN FOOD}

One example of this concern with saving time, while nonetheless maintaining tradition, may be seen in the packaging and preparation of Marguerite attiéké- "A traditional African dish [which is] Quick cooking." The packaging of Marguerite attiéké cassava couscous (see Figure 4) conveys this message of traditional production processes in two ways: first through the depiction of an attractive African woman carrying a tray of vegetables on her head and, second, through text that explicitly makes reference to authentic-traditional food production methods.

Try Marguerite attiéké, the delicious low fat couscous made from the cassava root. Produced using traditional method by women in Cote d'Ivoire on the coast of West Africa, attiéké is lighter in texture than regular couscous. It

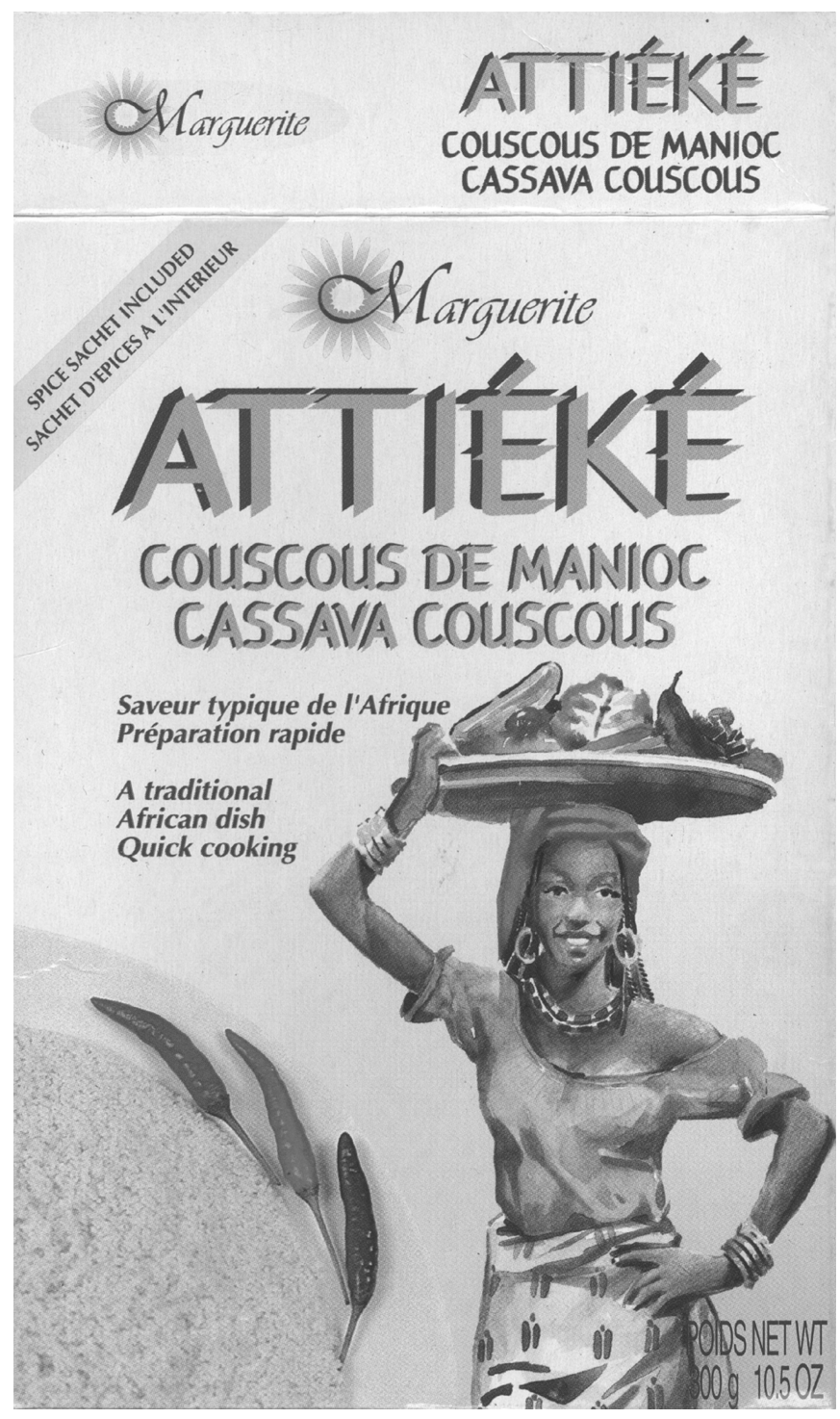

FIGURE 4. The packaging of quick-cooking Marguerite attiéké cassava couscous, "a traditional African dish," 2005. (Photograph by author) makes an excellent and healthy alternative to rice and pasta, for those of us who care about what we eat. Easy to prepare, attiéké makes an ideal accompaniment to all your meat, fish and vegetable dishes and salads. Marguerite Attiéké is a natural product, containing no artificial colors, or flavors and can be stored uncooked for up to 2 years. Marguerite wishes you "Bon appétit!"

What is particularly interesting about this text is that it also appeals to another aspect of the production, packaging, and marketing of African foods in the United States: namely, its reference to up-to-date health consciousness associated with educated, "enlightened" West Africans, those who "have arrived." Marguerite attiéké is a "low fat couscous" that "makes an excellent and healthy alternative to rice and pasta, for those of us who care about what we eat." It is also "easy to prepare and a natural product, containing no artificial colors, or flavors." Similarly, references to low cholesterol are made on the packaging of Golden Tropics ${ }^{\mathrm{TM}}$ Oatmeal Fufu, a recently marketed product. This appeal to healthy food differs considerably from the concerns of an average West African shopper who is focused on getting a good price for unspoiled produce. There are also concerns with health, nutrition, and hygiene, which are suggested by the elaborate packaging of snack foods that provide "nutrition facts" and expiration dates. It is not that snack foods such as chin chin or plantain chips are not easily available in motor parks (outdoor bus-taxi stations) throughout West Africa, but that where they are sold "packaging" is in slips of newspaper and recycled school exam papers without any indication of nutritional value or content. This is what distinguishes these foods and their consumers in West Africa from those in the United States.

The packaging of Marguerite attiéké also makes reference to time, although conjunctions of tradition and time may be somewhat contradictory. While parboiled rice is popular in many West African countries, in part because of its quick and easy preparation, many people still prefer the time-consuming preparation of boiling and pounding yams to make iyan rather than using the quick, instant-powdered versions, such as Ola Ola, which are sold in the United States and Nigeria. ${ }^{10}$ Frozen African-style dishes "packaged for today's family on the run" - such as those advertised on the website for Sheba Foods, founded in 2004 and based in Scottsdale, Georgia (Sheba Foods 2004; Shirreffs 2005), and Paani Foods, incorporated in 2004 and based in Chicago (Paani Foods 2005)_reflect this double concern with saving time and maintaining time-honored tradition. ${ }^{11}$ According to the Paani Foods website:

We prepare all food products from time-honored family recipes, passed down through the generations, with the freshest ingredients imported from Africa and the best produce grown locally....

We are a next-generation company promising to preserve the attributes of popular and beloved dishes, meat and poultry, and vegetables from the African tradition without the commitment of time in recreating this usually 
labor intensive cuisine. A meal is only minutes away in our Heat to Serve and Ready to Cook packaging. [Paani Foods 2005]

By using the technology of frozen food, consumers can have it both ways. It should be noted, however, that even in the United States where time constraints impose limits on choice, some people still prefer hand-pounded fufu or iyan, as an article in the October 2004 issue of the African Spectrum, a Chicago newspaper for a largely Ghanaian American audience, suggests:

Woodbridge, ILL: For those who crave for the taste of a real pounded Fufu, do not look too far. Mr. Cecil Quist of Woodbridge has the answer.

Armed with a mortar and pestle, Quist, who possesses a license to operate a restaurant, is ready to cater to your craving. On Sundays, one can call him and place an order.

"Even though there is a modern way of making the Fufu with a spatula [and powdered mix], I believe there is nothing that can be compared to the real traditional way of making the dish," says Quist who also is a talented artist. [African Spectrum 2004:27]

Nonetheless, the time-consuming responsibilities of jobs, child care and schooling, and church obligations, some of which might have been taken up by extended family members in West African societies, not only limit the amount of time available for the preparation of traditional dishes but also for religious and social events as well. For example, one C\&S church leader living in Brooklyn described the time constraints on church services in the United States while also noting the time and effort needed to prepare food for church anniversaries:

My church takes time, we know when we go we don't know when we are dismissing although they are trying to streamline things ... my elder in charge is a very busy man so he doesn't want to stay in church for 6 hours or so unless there is something special going on, so like now church is supposed to start at 9, we start at 9, even if it is two people who are there so you find by 12 , latest 1 , you find that church is over...

You know my church we always cook most often we cook at the church like my branch here where I go to we have a hall with kitchen and everything. ... In two weeks I have a big anniversary coming up which I'm dreading kind of ... because like it or not, some people don't know how to cook for a large group. So I have to do more than I'm expected to do. [Interview with C\&S Church woman church leader, Brooklyn, New York, October 29, 2005]

Under such circumstances, women involved in preparing food for large groups at church anniversaries and other ceremonial events might rely, to some extent, on processed ingredients. Despite being technologically very different in their production methods from West African cuisines from "home," these processed foods represent an ideal of taking the time to maintain traditional food practices, thus reinforcing particular social identities, which are, nonetheless, changing.

\section{WEST AFRICAN FOOD AND CHANGING SOCIALITY}

Through their preparation of specific West African cuisines (Nigerian, Yoruba, Igbo, Ghanaian, and Akan), West African immigrants maintain ethnic and national identities and reinforce particular social ties in the United States. Refreshments such as Jollof rice, fried plantains, pounded yam, and at times egusi soup, prepared and consumed in branches of U.S.-based Cherubim and Seraphim Churches put members at ease with the "comfort food" of home, Nigeria. ${ }^{12}$ Church events are also a source of information about where to obtain particular West African foodstuffs. For example, one Nigerian American woman who went to a meeting at a fellow church member's house was served a dish specific to Niger Delta that she had wanted to prepare but had been unable to because she couldn't find a particular ingredient. She was told that this ingredient was sold at one of the grocery chains in New York City but even after going to four stores she could not find it. However, she was reassured by another church member who told her that she would bring it to their next church meeting (Interview, C\&S woman church leader, Newark, New Jersey, October 30, 2005).

This example of the sharing of sources for distinctive ethnic cuisines prepared by C\&S Church members, who were originally largely Yoruba-speaking men and women from southwestern Nigeria, underscores that fact that many C\&S Churches in West Africa and the African Diaspora now include members from other Nigerian ethnic groups, including Igbo, Ijo, Itsekiri, and Bini men and women, with their own distinctive cuisines. While specific Igbo dishes may be served at smaller meetings, the food served after church services often represents a more collective Nigerian national identity (Cusack 2000). Thus, at the 2005 Thanksgiving service at House of Gideon C\&S Church, in Newark, New Jersey, food for guests consisted of Jollof rice, fried plantains (dodo), fried meat (eran), and small meat pies: in other words, generic Nigerian, or even more generally West African, cuisine was served to churchgoers.

This generalized Nigerian cuisine is particularly appropriate fare at services of the U.S. branches of the C\&S Church, which includes members from several different parts of Nigeria, whose distinctive ethnic identities are merged within the U.S. churches in which membership is pooled from a smaller number of Nigerian American C\&S Church members. This situation differs considerably from attendance at the many branches of C\&S Churches in Nigeria, which are often associated with individual founders from particular places. In such cases, distinctive food preferences prevail, exemplified by the relative stiffness or softness of pounded yam, accomplished by the amount of water added, and by its pliancy, which depends on the age of the yams used, the amount of water added, and the extent of pounding. The "traditional" artisanal technologies associated with mortar and pestle use allow for these distinctive food tastes associated with different Nigerian places (Revel 1982). Similarly, the laborious preparation of named dishes such as the Yoruba akara (in Igbo, akara; in Hausa, 
kosai)-bean fritters made of skinned and ground blackeyed peas along with the particular concatenation of pepper, onions, and spices, fried in palm oil, which have their own particular tastes, textiles, and shapes-relate these foods to particular ethnic identities: Yoruba, Hausa, or Igbo. The preparation of such food also links itself to particular places: for example, the town of Oshu, on the road between Ilesha and Ile-Ife, which specializes in akara sales to travelers; the corner opposite Pada Primary School in Zaria City, in northern Nigeria, where one woman cooks and sells kosai to passersby every morning; and the Onitsha Market, where akara bean fritters are sold with pap to traders in the early morning. Alternately, despite the different brandnames of mass-produced and -packaged yam flours such as Ola-Ola $^{\mathrm{TM}}$, Mimi Worldwide Foods, and Iyan Ado advertised on the website for Cayce Foods (2006) and akara mixes available at African grocery stores, except for slight differences in how closely they approximate the actual mortar and pestle-pounded yams or akara fritters when prepared, the results of these packaged yam flours and akara mixes are very much the same.

Thus, in the United States, specificities of African ethnicity, language, and place are often downplayed in favor of a broader national, regional, or global identity when referring to food. The parents of the young Nigerian American writer Uzodinma Iweala reinforced his ethnic connections with particular Igbo villages and his knowledge of the Igbo language, but he refers to food, as well as himself, with a more generic Nigerian identity:

\begin{abstract}
My parents have always stressed the Nigerian aspect of my person through our family's yearly trips to the villages in which my mother and father grew up, the speaking of the Nigerian Igbo language in our house, and the cooking of Nigerian food that tastes better than anything you've previously ingested. The mantra of my childhood was "remember where you come from." [Iweala 2006: PS, p. 4]
\end{abstract}

This process of a shift toward national and regional cuisines also has taken place in West Africa with the import of manufactured Western foodstuffs into Nigeria during the colonial period, such as tinned, condensed milk; sardines; Maggi cubes; and white bread (Goody 1982:176). ${ }^{13}$ This homogenization of food tastes was further reinforced during the Independence period, through media advertisements, television cooking shows, and contests, as well as newspaper columns about food and cookbooks (Mars and Tooley 1943), all of which have contributed to a sense of a Nigerian national cuisine (Cusack 2000; Ikpe 1994). Yet specific local food preferences continue, such as for tuwo shinkafa, a rice porridge that is favored in northern Nigeria when prepared in the traditional way, boiled and pounded (Ikpe 1994:216).

In the United States, the packaging of West African products reminds consumers of these "timeless" but timeconsuming West African production techniques-for example, mortar-and-pestle pounding, stone grinding, and hand shelling — that are used in their processing back home, yet product branding with names such as "All African Nations Foods" or "Golden Tropics ${ }^{\mathrm{TM}}$ " reinforce a more globaltransnational African and American identity. This broader identity is further reinforced on some packaging of West African foods sold in U.S. grocery stores through the practice of listing the names of the product in several different languages. For example, "Crunch Plantain Strips" are also described on the packaging as ipekere and platanos (Igbo and Spanish, respectively), while the packaging of "instant Ogi," the processed version of the sour cornstarch breakfast food of Soyinka's childhood, is written as akamu, koko, and pap (Igbo, Yoruba, and English). ${ }^{14}$

Furthermore, some products also make reference to the entire African continent and subsequently all Africans through their logos, trademarks, and package illustrations (see Figure 3). Thus, the packaging for Golden Tropics Plantain Fufu Flour depicts the national flags of Liberia, Guinea, Togo, Cote d'Ivoire, Sierra Leone, Cameroon, Senegal, Benin, and Ghana (see Figure 5). Yet this imagery of West African solidarity is belied by the prominence of place given to the Ghanaian flag-Golden Tropics products are manufactured in Tema, Ghana, and packaged in Newark, New Jersey-and the absence of the Nigerian flag. Thus, there are both collective and conflicting identities (family, ethnic, national, regional, and transnational) represented here, as well as a range of social frames (modern and upto-date, yet respectful of African traditions), that are reinforced by particular foods associated with West Africa that have been transformed by the new technologies used in their preparation.

\section{DISCUSSION}

Aro meta eeyi (Three hearthstones don't shake [the cook pot]).

-Bunu Yoruba saying

The saying aro meta eeyi, "three hearthstones don't shake," suggests the image of the blackened cook pot, seated on three hearthstones (aro meta), that will not shake, fall down, or break (Renne 1995:74). The phrase is used in situations when one wants to evoke a sense of firmness, strength, and groundedness. It is appropriate, then, that the image of the cook pot serves as a logo on West African food packaging, referring to this sense of stability and connections to one's African roots and home. The cook pot also represents a certain technique of food preparation associated with indulgent mothers who cook delectable soups and stews made with palm oil, egusi seeds, bitter leaf, and peppers over hot fires, imagery that is fondly associated with memories of certain times and places. The memories of place associated with the tastes, aromas, and textures of particular foods, prepared by the labor-intensive techniques associated with cooking with a large pot over an open, smoky fire, using local ingredients, perhaps explain why some Nigerians, on returning home from the United States, prefer to eat street food and locally prepared 


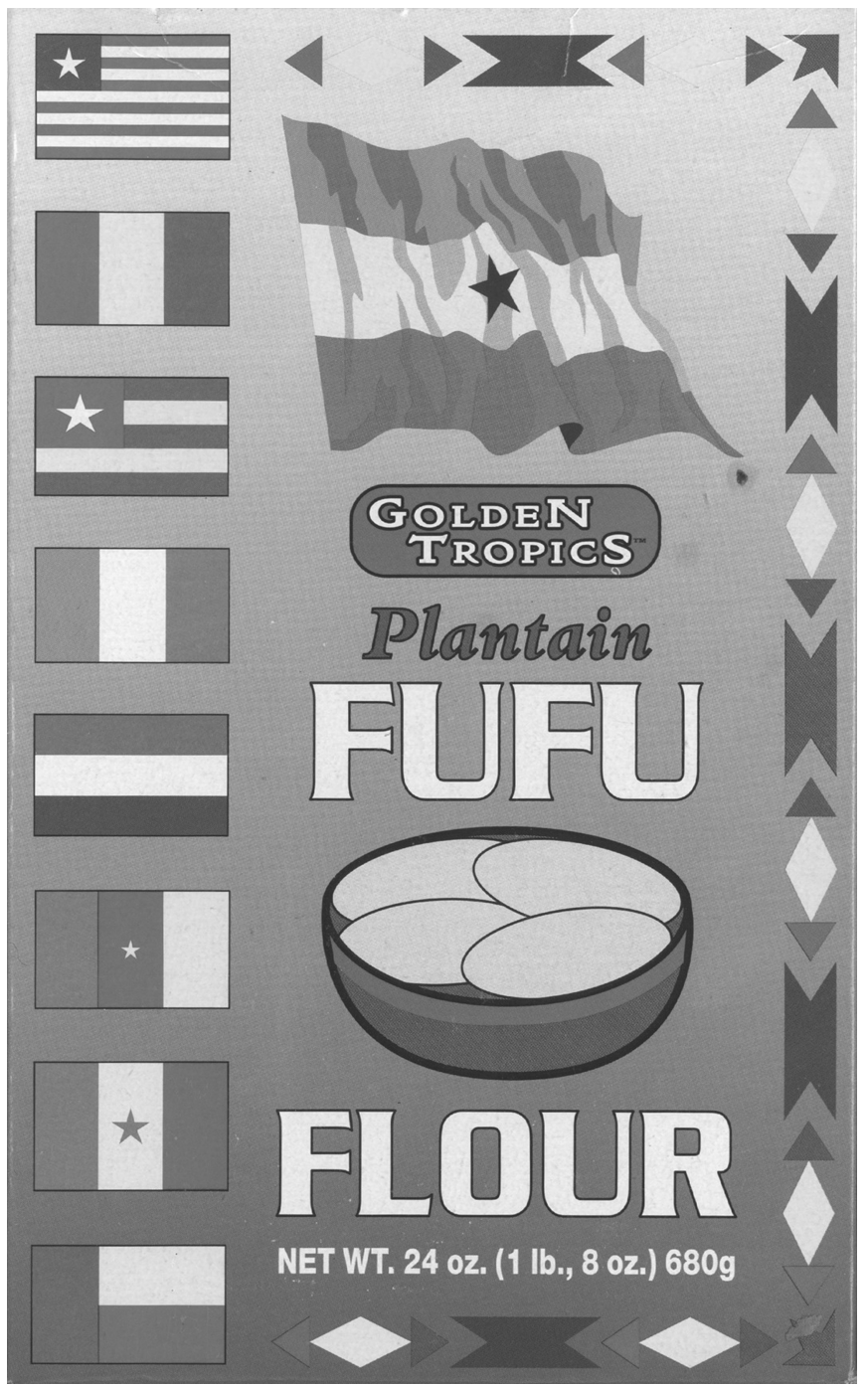

FIGURE 5. Front packaging of Golden Tropics ${ }^{\mathrm{TM}}$ plantain fufu flour, with several African national flags and the Ghanaian flag prominently displayed, 2005. (Photograph by author)

cuisine. For example, when the proprietress of the Wazobia West African grocery store in Brooklyn returns to Lagos, she noted that:

I don't eat at Tantalizers [a fast-food chain in Nigeria], I go to the buka [small restaurants run by women who prepare local cuisine] and order amala (a porridge made from yam flour, usually served with obe ila, an okra soup), then I will just point to different pots [of meat and fish] and say, "I'll have that and that and that." [Interview, Brooklyn, August 26, 2006]

The anticipation of eating these much-loved foods produced by hand, using local materials and cooking techniques, is one of the pleasures of returning home, be it to Lagos, or Accra, or Enugu. While the packaging of Paani frozen moyin moyin (steamed bean cakes) makes reference to the ideal of leaf-wrapping, thus seeking to draw on these associations of home, food, and traditional cooking techniques, the resulting product-the frozen unwrapped version-cannot be compared with the original. For there are certain expectations of what good moyin moyin should be: firm but smooth and slightly peppery, sometimes enhanced with bits of smoked fish and crawfish, with small ridges formed on its surface by its leaf wrapping. While the preparation of moyin moyin is neither uniform nor unchanging, it does have a long history of production and consumption in southwestern Nigeria.

Similarly, when one of the elders at a C\&S church service in the Bronx told the congregation of his recent trip to Nigeria, he described his delight in eating $e k o$, a sort of firmer version of ogi, that had been wrapped in banana leaves rather than in pieces of plastic. Indeed, this appreciation of well-prepared eko, wrapped in banana leaves and served with a pepper sauce, has been documented by the African American traveler, Robert Campbell, who traveled in Nigeria in the 19th century:

\begin{abstract}
The food of the Egbas, as well as of all the tribes between Lagos and Ilorin, is very simple, consisting of a preparation called $e k o$ : corn is macerated in water until fermentation ensues. It is then crushed between stones, and the chaff separated by washing. The milky liquor is then boiled in large pots until it assumes a consistency somewhat stiffer than cream, which as it cools becomes as firm as jelly. The taste is rather unpleasant at first, but one seldom fails to like it after persisting in its use. A portion of it nearly as large as a penny-roll, wrapped in leaves, is sold for five cowries, or about a mill. An adult native consumes from four to eight at a meal, taking with it as a relish a few spoonsful of obé, or "palaver-sauce," as the Sierra Leone folks call it. Palaver-sauce is made by cooking together palm-oil, pepper, ocros [okra], locust-seed, ogiri [cooked egusi melon seed] and several succulent herbs ... Ground beans and pepper, fried in oil, called acras [akara]; cooked yams, beaten with water in a wooden mortar, fufu; with certain other preparation of corn, rice, etc., also form part of the diet. [Campbell 1861:44-45]
\end{abstract}

That a C\&S church elder in the Bronx recounts his pleasure in eating leaf-wrapped eko 150 years later attests to the long-standing preferences for certain combinations of starchy porridges served with savory soups among West African men and women (Lentz 1999:15).

\section{CONCLUSION}

Despite these older food preferences, many West Africans living in the United States also consider themselves to be people "on the move," as those who have "made it." They have changed their food preparation practices-and, in some cases, their food preferences-for reasons of time and health. ${ }^{15}$ The technologies of mass production of West African foods-canned, powdered, and frozen-are particularly appropriate for these individuals, who idealize the labor-intensive techniques of African food preparation yet pride themselves in their modern U.S. lifestyles, which would not permit them to prepare foods in such a way in actual practice. The development during the 1980s and 1990s in the United States of a certain configuration of 
global assemblages-manufactured West African foods, African brand-named products, specialty African grocery stores, and advertisements in U.S.-produced African newspapers-has allowed West African men and women living abroad to maintain their memories of food and African childhood as well as global connections with their families, hometowns, religious and ethnic groups, and national associations. Anthropologist Lynne Phillips refers to this "process of culture-making [as] a central component of globalization" (2006:46). One particular aspect of this "process of culture-making" may be seen in the time-saving techniques and homogeneity of processed West African food preparation, which allows West African migrants and their U.S.-born descendents to stress both their transnational global and particular family and ethnic identities to a greater or lesser extent.

Elisha P. Renne Department of Anthropology and The Center for Afroamerican and African Studies, University of Michigan, Ann Arbor, MI 48109-1107

\section{NOTES}

Acknowledgments. An earlier draft of this article was presented at the panel "Food and Drink: Techne and Technoscience" at the American Anthropological Association annual meetings in Washington, D.C., November 2005. I would like to thank the panel organizers, Deborah Heath and Anne Meneley, as well as fellow panelists for their suggestions and insights. I am also grateful to Patience Jones for facilitating my attendance at $C \& S$ church services and to Olufunke Okome for introducing me to West African grocery stores in the New York metropolitan area.

1. Ebiripo is a type of yam dish. Ikokekore is made by boiling peeled and grated yams with smoked fish and ground shrimps, palm oil, pepper, salt, and onions (Bascom 1951b:135, citing Mars and Tooley 1943).

2. I first learned of this way of making fufu from the wife of a Ghanaian professor at a small college in Florida in the mid-1970s.

3. I focus on West African cuisine, primarily because many of the grocery stores and food manufacturers cater to Nigerian and Ghanaian immigrants. There are a few exceptions, however; Paani, the purveyor of African frozen meals, has added an East African dish, Wali wa Nazi, to its choices, most of which are Nigerian fare. 4. There are two websites that list African grocery stores in the United States and Canada: African Markets website (http://www.africanchop.com/chopso.htm) and the African Grocery Stores-U.S. website (http://afrodrive.com/AfricanStores/ default. asp?WCountryID=2).

5. An earlier portion of this study of the Cherubim and Seraphim Church was conducted in Nigeria in 2002 and 2003, focusing on religious textiles in southwestern Nigeria (Renne and AgbajeWilliams 2005). My familiarity with Nigerian cuisine comes from conducting research in the Niger Delta (1985), southwestern Nigeria $(1987-88,1990,1991-92,1993,2002,2003,2004)$, and northern Nigeria (1994-95, 1996, 1997, 1998, 1999, 2000, 2001, 2005, 2006).

6. The Akan word sankofa means, literally, "return and get it" but is also translated as "we must go back and reclaim our past so we can move forward." It is represented on Asante funeral cloths by the adinkra symbol, $\mathbf{C}$. It is also the title of a film (1993) directed by Haile Gerima, the storyline of which revolves around the idea of memory, the past, and return.

7. Wazobia is the name of a proposed national language that combines elements of the Yoruba, Hausa, and Igbo, the three main language and ethnic groups in Nigeria. The term Wazobia consists of words meaning "come" in Yoruba (wa), Hausa (zo), and Igbo (bia). Its use signals its specialization in Nigerian foodstuffs and, more recently, Nigerian films.

8. The many named varieties of yams are indicative of their pride of place in Yoruba cuisine. There are over 37 named varieties of white yam, Discorea rotundata, alone (see Bascom 1951a:44; OsseoAsare 2005:18-20). Yams are celebrated in festivals and in folktales. In June and early July, people in towns and villages in southwestern Nigeria observe the New Yam Festival, after which people can freely eat the new crop of yams. Yams are also described as having human qualities, traveling to streams during droughts to drink water (Renne 1995:227n20). L. C. Okere (1983:93-105) discusses the importance of yams in Igbo society and cuisine, referring to the yam as "the King of Crops" (Okere 1983:212).

9. Deborah Lupton (1994) notes that in Australia certain foods evoke vivid childhood memories, which may sometimes be unpleasant (on food and childhood in Australia, see also Renne 1993). 10. There are several companies producing instant, pounded yam flour. One of the earliest brand-names was Pound-o, which was marketed in the United States and Nigeria in the late 1980s. More recent brand names include Ola-Ola, Iyan Ado, and Mimi Worldwide Foods.

11. Kunmi Oluleye, the founder of Sheba Foods, was born in Lagos, Nigeria. She sells many items familiar to Nigerian immigrants, such as frozen okra soup and frozen Jollof rice, as well as fresh goat meat. Part of her marketing strategy has been to provide foods through a store in Scottsdale, Georgia, through the Sheba Foods website (2004), and through large grocery chains including Wal-Mart and Publix (Shirreffs 2005).

12. "Refreshments," the final item on the C\&S Church Women's Anniversary Service program held at the Bronx C\&S Eternal Sacred Order Church, on August 27, 2006, included Jollof rice with fried chicken, plantains, and green peppers; egusi soup and pounded yam (Ola Ola brand); and soft drinks and bottled water.

13. While British colonial officials were responsible for introducing Nigerians and Ghanaians to white bread, its production was soon taken up by small local bakeries (Goody 1982; Ikpe 1994) and is very popular as a fast-food in both countries. The type of bread favored is soft and white, often produced in large rectangular loafs. I have seen Nigerians carrying this bread with them when traveling overseas; it is also available at Wazobia Grocery Store in Brooklyn.

14. Koko is described as a type of "eko in which the ogi is lumpy" (Abraham 1962:379). Using an instant mix would facilitate making lumpy eko.

15. As one Ghanaian Nigerian American man described this change in his diet, "My favorite food is jollof rice. But now, due to health purposes, I eat more vegetables, less oil 'efo.' I don't eat too much meat, mostly fish and organic chicken, like home chicken" (African Abroad-USA 2006:37).

This man exemplifies the sorts of multiple national identities that are not uncommon in West Africa. He was born in Ghana; later traveled to Kaduna, Nigeria, where he had connections through his Hausa background; and then later went back to Ghana. Since coming to the United States in 1980, he has established the One Stop African Market and an African restaurant in the Bronx.

Oil "efo" is a boiled leafy vegetable dish prepared with red oil, onions, and dried fish.

\section{REFERENCES CITED}

Abraham, R. C.

1962 Dictionary of Modern Yoruba. London: Hodder and Stoughton.

African Abroad-USA

2006 "It Is a Blessing to be in the USA!": Mohammed. African Abroad-USA 7(16):37.

African Spectrum

2004 Pounded Fufu in the Suburbs. African Spectrum 6(6):27

Ajibola, J. O., and B. Somade

1947 Ounje Ile Yoruba (The food of Yorubaland). London: Oxford University Press. 
Bascom, William R.

1951a Yoruba Food. Africa 21(1):41-53.

1951b Yoruba Cooking. Africa 21(2):125-137.

Beidelman, T. O.

1985 Moral Imagination in Kaguru Modes of Thought. Bloomington: Indiana University Press.

Bowen, T. J.

1968[1857] Adventures and Missionary Labours in Several Countries of the Interior of Africa from 1849 to 1856 . London: Frank Cass.

Campbell, Robert

1861 A Pilgrimage to My Motherland: An Account of a Journey among the Egbas and Yorubas of Central Africa in 1859-1860. New York: Thomas Hamilton.

Cayce Foods, Inc.

2006 Cayce Foods, Inc. Electronic document, http://www. caycefoods.com, accessed August 30.

Curtin, Deane W.

1992 Recipes for Values. In Cooking, Eating, Thinking: Transformative Philosophies of Food. D. Curtin and L. Heldke, eds. Pp. 123-144. Bloomington: Indiana University Press.

Cusack, Igor

2000 African Cuisines: Recipes for Nation-Building? Journal of African Cultural Studies 13(2):207-225.

Ekariko, Phylis

2005 Akara: The Fast Food with a Painstaking Preparation. Afrique 16(11):14.

Gerima, Haile, dir.

1993 Sankofa. 125 min. Mypheduh Films. Washington, DC.

Goody, Jack

1982 Cooking, Cuisine and Class: A Study in Comparative Sociology. Cambridge: Cambridge University Press.

Holtzman, J. D.

2006 Food and Memory. Annual Review of Anthropology 35:361-378.

Ikpe, Eno B.

1994 Food and Society in Nigeria: A History of Food Customs, Food Economy, and Cultural Change, 1900-1989. Stuttgart: Franz Steiner.

Iweala, Uzodinma

2005 Beast of No Nation. New York: HarperCollins.

Lentz, Carola, ed.

1999 Changing Food Habits: Case Studies from Africa, South America, and Europe. Amsterdam: Harwood Academic.

Lupton, Deborah

1994 Food, Memory, and Meaning: The Symbolic and Social Nature of Food. Sociological Review 42(4):664687.
Mars, J. A., and E. M. Tooley, eds.

1943 The Kudeti Book of Yoruba Cookery. Lagos: Church Missionary Society Bookshop.

Okere, L. C.

1983 The Anthropology of Food in Rural Ibgoland, Nigeria. London: University Press of America.

Omoyajowo, J. A.

1982 Cherubim and Seraphim: The History of an African Independent Church. New York: Nok Publishers International.

Osseo-Asare, Fran

2005 Food Culture in Sub-Saharan Africa. Westport, CT: Greenwood Press.

Paani Foods

2005 Paani Foods, Inc. Electronic document, http://www. paanifoodsinc.com, accessed August 31, 2006.

Pavitt, Jane, ed.

2005 In Goods We Trust. In Brand.New. J. Pavitt, ed. Pp. 19-51. Princeton: Princeton University Press.

Peel, J. D. Y.

1968 Aladura: A Religious Movement among the Yoruba. Oxford: Oxford University Press, for the International African Institute.

Phillips, Lynne

2006 Food and Globalization. Annual Review of Anthropology $35: 37-57$

Renne, Elisha

1993 "All Right, Vegemite!": The Everyday Constitution of an Australian National Identity. Visual Anthropology 6(2):139155.

1995 Cloth That Does Not Die. Seattle: University of Washington Press.

2003 Population and Progress in a Yoruba Town. Edinburgh: University of Edinburgh Press.

Renne, Elisha, and Babatunde Agbaje-Williams

2005 Yoruba Religious Textiles. Ibadan: Book Builders.

Revel, Jean-Francois

1982 Culture and Cuisine. New York: Doubleday.

Sheba Foods

2004 Sheba Foods. Electronic document, http://www.sheba foods.com, accessed April 27, 2007.

Shirreffs, Allison

2005 Homemade Recipe Genesis for Product Success. Atlanta Business Chronicle, February 18-24:48.

Soyinka, Wole 1981 Aké: The Years of Childhood. Ibadan: Spectrum.

Sutton, David

2001 Remembrance of Repasts: An Anthropology of Food and Memory. London: Berg. 